AgNiesZKa NitSZKF.

Instytut Nauk Politycznych i Stosunków Międzynarodowych

Uniwersytet Jagielloński

\title{
Reforma WsPólnego EUROPEJSKIEgO \\ SYSTEMU AZYLOWEGO W DOBIE KRYZYSU MIGRACYJNEGO ${ }^{1}$
}

\section{UWAGI IVSTERPE.}

Kryzys migracyjny wywołany wydarzeniami Arabskiej Wiosny, a następnie wojną domową w Syrii rzucił Unii Europejskiej (UE) jedno z najpoważniejszych wyzwań integracyjnych w historii. Skala migracji, a także różnice w podejściu państw członkowskich do zaistniałej sytuacji unaoczniły niedoskonałości tworzonego od późnych lat 90. XX w. Wspólnego Europejskiego Systemu Azylowego (WESA). Analizując kryzys migracyjny zapoczątkowany w 2011 r., należy zwrócić uwagę na definiowanie podstawowych pojęć. Często w debacie publicznej dotyczącej omawianej kwestii dochodzi do wymiennego stosowania terminów „migracja” i „azyl”. Pewne kontrowersje pojawiają się również w odniesieniu do stosowania samego terminu „kryzys”. W Stowniku jęzka polskiego PWN kryzys jest definiowany jako „sytuacja, w której jakiś konflikt staje się tak poważny, że grozi wybuchem wojny, zmianą rządu lub innym radykalnym rozwiązaniem [lub jako - A.N.] zachwianie jakiegoś systemu wartości lub pozycji czegos'”2. W sytuacji, do której doszło w UE, z pewnością te przesłanki nie zachodzą, niemniej skala i konsekwencje migracji okazały się na tyle poważne, że w potocznym ujęciu określono je jako kryzys. Dużo ważniejsze jest jednak prawidłowe zdefiniowanie i rozgraniczenie pojęć „polityka migracyjna” i „polityka azylowa”. Biuro Wysokie-

Artykuł został napisany w ramach grantu Jean Monnet Chair EUCRIS: European Union in Crisis: What Is Wrong and How to Fix It? (nr 575240-EPP-1-2016-1-PL-EPPJMO_CHAIR).

2 Kryzys [hasło], [w:] Stownik jezyka polskiego PWN, [on-line:] https://sjp.pwn.pl/sjp/kry zys;2565070.html - 25.04.2019. 
go komisarza Narodów Zjednoczonych do spraw uchodźców (Office of the United Nations High Commissioner for Refugees - UNHCR) podaje uproszczoną, ale bardzo obrazową definicję:

[...] osoby wkraczające na terytorium Europy nielegalnie robią to $\mathrm{z}$ wielu powodów. W niektórych przypadkach są to migranci ekonomiczni próbujący uciec od ubóstwa i bezrobocia. W niektórych innych - uciekinierzy przed prześladowaniami, łamaniem praw człowieka lub konfliktami zbrojnymi. Bardzo często nielegalne dostanie się na terytorium państwa jest ich jedyną drogą ucieczki. Uchodźcy i migranci często podróżują razem, korzystając z tej samej trasy i środka transportu. Jednak ich sytuacja w zakresie konieczności ochrony bardzo się różni: migranci wybrali zmianę miejsca zamieszkania, podczas gdy uchodźcy musieli to zrobić3 ${ }^{3}$.

Właśnie ta kwestia - rozróżnienia między "uchodźcą" a "migrantem” i co z tym związane: kwestia zastosowania przepisów z zakresu polityki azylowej czy migracyjnej stała się jednym z głównych punktów sporu pomiędzy podmiotami kreującymi i realizującymi politykę w Unii Europejskiej.

Celem artykułu jest przedstawienie podstawowych założeń Wspólnego Europejskiego Systemu Azylowego, a następnie skonfrontowanie ich funkcjonowania w obliczu kryzysu, oraz, następczo, reakcje Unii Europejskiej na uwidocznione niedoskonałości tych rozwiązań. Autorka stawia następujące pytania badawcze: Czy kryzys migracyjny wzmocnił solidarność Unii Europejskiej w zakresie polityki migracyjnej i azylowej? Czy można wyznaczyć wyraźną linię demarkacyjną pomiędzy polityką migracyjną a polityką azylową? Jakie konsekwencje dla integracji europejskiej przyniósł kryzys migracyjny?

Postawiono następującą hipotezę badawczą: kryzys migracyjny, zwłaszcza jego kulminacja $z$ lat 2015-2016, wpłynął na wypracowanie i przyjęcie skuteczniejszych mechanizmów w polityce azylowej, które pozwolą efektywniej zarządzać kolejnymi zwiększonymi migracjami do UE4.

W artykule zastosowano przede wszystkim metodę instytucjonalno-prawną opartą na analizie dokumentów UE oraz metodę systemową pokazującą miejsce polityki azylowej w strukturze innych polityk przez pryzmat procesu decyzyjne-

Azyl i migracja. Wszyscy na tym samym wózku, 20.12.2016, [on-line:] https://www.unhcr.org/ pl/235-plco-robimymonitorowanie-granicazyl-i-migracja-html.html - 25.03.2019.

4 Komisja Europejska podkreśla, że w przyszłości należy liczyć się z kolejnymi zwiększonymi napływami migracyjnymi, które mogą być powodowane zmianami klimatu, destabilizacja kolejnych regionów i in. Przyszłość polityki migracyjnej, Komisja Europejska. Przedstawicielstwo w Polsce, 7.12.2017, [on-line:] https://ec.europa.eu/poland/news/171207_migration_pl 25.03.2019. 
go, a także relacji między instytucjami Unii Europejskiej i między instytucjami a państwami członkowskimi, gdzie nie bez znaczenia są relacje między samymi państwami członkowskimi - zauważalna i wyraźna stała się linia podziału na nowe i stare państwa członkowskie UE.

\section{Wspóliy Eliropejski Systey Azyloiry}

Początkiem prac nad ustanowieniem WESA było posiedzenie Rady Europejskiej (RE) w Tampere w czasie prezydencji Finlandii w październiku 1999 r. $^{5}$ WESA należy postrzegać bardziej w kategoriach procesu aniżeli jednostkowej decyzji, której efektem byłoby ustanowienie instytucji odpowiedzialnej za realizację polityki azylowej w UE 6 . Przywódcy państw UE, mając na uwadze specyfikę polityki azylowej, postanowili rozłożyć prace nad systemem na etapy, tak by w razie konieczności móc dokonywać korekt i modyfikacji?

Wejście w życie traktatu lizbońskiego w 2009 r. stworzyło ramy prawne dla dalszego rozwoju WESA. Kwestie polityki azylowej są regulowane w art. 78 Traktatu o funkcjonowaniu Unii Europejskiej (TFUE), który stanowi:

1. Unia rozwija wspólną politykę $w$ dziedzinie azylu, ochrony uzupełniającej i tymczasowej ochrony, mającą na celu przyznanie odpowiedniego statusu każdemu obywatelowi państwa trzeciego wymagającemu międzynarodowej ochrony oraz mającą na celu zapewnienie przestrzegania zasady non-refoulement. Polityka ta musi być zgodna z Konwencją genewską z dnia 28 lipca 1951 roku i Protokołem z dnia 31 stycz-

Tampere European Council 15 and 16 October 1999, Presidency Conclusions, s. 2-3, [on-line:] https://www.consilium.europa.eu/media/21059/tampere-european-council-presidency-con clusions.pdf - 25.03.2019.

6 Komentarze do decyzji RE z Tampere odnośnie do tworzenia WESA były bardzo zróżnicowane. Część autorów wskazywała, że proponowane rozwiązania nie zawierają żadnego nowego elementu, który mógłby zmienić podejście państw i UE do polityki azylowej. Zob. R. Wein zierl, Flüchtlinge. Schutz und Abwehr in der erweiterten EU. Funktionsweise, Folgen und Perspektiven der europäischen Integration, Baden-Baden 2005, s. 98, Schriftenreihe europäisches Recht, Politik und Wirtschaft, Bd. 308. Z kolei inni autorzy, m.in. Izabela Wróbel, przedstawiaja zgoła odmienne podejście, podkreślając, że w traktacie o WE w wersji z Amsterdamu, który wszedł w życie 1 maja 1999 r., nie ma w ogóle mowy o WESA, a zatem zapowiedź z Tampere należy traktować jako novum w procesie integracji politycznej UE. Zob. I. Wróbel, Wspólny europejski system azylowy - stan obecny i perspektywy rozwoju, Warszawa 2012, s. 6-7, Materialy Robocze, $\mathrm{nr} 1$ (17).

Więcej na temat genezy i rozwoju WESA od 1999 do 2012 r. zob. A. Nit szke, Polityka azylowa Unii Europejskiej. Między idealizmem a realizmem, [w:] Dylematy strategiczne XXI wieku, red. R. Kłosowicz, B. Szlach ta, J. J. Węc, Kraków 2013, s. 353-365. 
nia 1967 roku dotyczącymi statusu uchodźców, jak również z innymi odpowiednimi traktatami ${ }^{\mathrm{B}}$.

Co istotne, w ust. 2 tego artykułu doprecyzowano, że Parlament Europejski i Rada, przyjmując środki dotyczące WESA, stanowią zgodnie ze zwykłą procedurą ustawodawczą. W dalszej części przytoczonego ustępu określono elementy składowe WESA, którymi są: po pierwsze, jednolity status azylu dla obywateli państw trzecich, obowiązujący w całej Unii; po drugie, jednolity status ochrony uzupełniającej dla obywateli państw trzecich, którzy nie uzyskawszy azylu europejskiego, wymagają międzynarodowej ochrony; po trzecie, wspólny system tymczasowej ochrony wysiedleńców na wypadek masowego napływu; po czwarte, wspólne procedury przyznawania i pozbawiania jednolitego statusu azylu lub ochrony uzupełniającej; po piąte, kryteria i mechanizmy ustalania państwa członkowskiego odpowiedzialnego za rozpatrywanie wniosku o udzielenie azylu lub ochrony uzupełniającej; po szóste, normy dotyczące warunków przyjmowania osób ubiegających się o azyl lub o ochronę uzupełniającą; po siódme, partnerstwo i współpraca z państwami trzecimi w celu zarządzania przepływami osób ubiegających się o azyl lub o ochronę uzupełniającą lub tymczasową ${ }^{9}$ W ust. 3 art. 78 zapisano, że w sytuacji, gdy któreś z państw członkowskich UE znajdzie się w sytuacji zwiększonej presji migracyjnej, Rada, na wniosek Komisji Europejskiej i po konsultacji z PE, może przyjąć środki tymczasowe na korzyść takiego państwa.

Przed rozpoczęciem kryzysu migracyjnego, bazując już na nowych przepisach traktatowych, udało się przyjąć rozporządzenie w sprawie utworzenia Europejskiego Urzędu Wsparcia w dziedzinie Azylu (European Asylum Support Office EASO $)^{10}$. Ze względu na wielość podmiotów i idące za tym rozproszenie kompetencji w obszarze polityki azylowej postanowiono stworzyć wyspecjalizowaną agencję, której zadaniem byłoby wzmocnienie współpracy między instytucjami UE i państwami członkowskimi w sprawach azylu, wspieranie państw, których systemy azylowe znajdują się pod szczególną presją, oraz usprawnienie procesu wdrażania wspólnego europejskiego systemu azylowego. Zgodnie z rozporządzeniem tworzącym EASO jest on odpowiedzialny nie tylko za ułatwianie wymiany informacji oraz identyfikację i zbieranie najlepszych praktyk $\mathrm{w}$ dziedzinie azy-

Traktat o funkcjonowaniu Unii Europejskiej, Dz. Urz. UE C 202 z dnia 7 czerwca 2018, s. 76-77. Ibidem.

10 Rozporządzenie Parlamentu Europejskiego i Rady (UE) nr 439/2010 z dnia 19 maja 2010 r. w sprawie utworzenia Europejskiego Urzędu Wsparcia w dziedzinie Azylu, Dz. Urz. UE L 132 z dnia 29 maja 2010. 
lu w skali UE, ale także śledzenie i analizowanie rozwiązań międzynarodowych $\mathrm{w}$ tym zakresie. Jednym $\mathrm{z}$ ważniejszych zadań postawionych przed tą agencją jest stworzenie i rozwijanie portalu internetowego, gdzie zamieszczane są informacje o trendach i głównych problemach związanych z polityką azylową. EASO odpowiada także za sporządzanie analiz i sprawozdań dotyczących krajów pochodzenia osób ubiegających się o azyl w Unii ${ }^{11}$.

Kolejne działania UE w zakresie rozwoju WESA podejmowane były już w obliczu początkowych symptomów kryzysu migracyjnego. Pierwsza fala zwiększonej presji migracyjnej zaistniała w 2011 r., wówczas też pojawiły się kontrowersje związane $z$ odpowiedzialnością państw za zarządzanie kryzysem migracyjnym. Najbardziej znanym przykładem konfliktu na tym tle był spór pomiędzy Włochami i Francją. Włochy, do których od początku 2011 r. zaczęły napływać tysiące uchodźców z Tunezji, a potem także z Libii, postanowiły przyznać części z tych osób tymczasowe wizy Schengen, umożliwiające im opuszczenie Włoch. W kwietniu 2011 r. pociąg z uchodźcami z Tunezji został zatrzymany na granicy włosko-francuskiej. Ówczesny prezydent Francji Nicolas Sarkozy podjął decyzję o niewpuszczeniu uchodźców na teren Francji. Wywołało to falę dyskusji o polityce azylowej UE i solidarności między państwami członkowskimi ${ }^{12}$. W tamtym czasie nikt nie był w stanie przewidzieć, że prawdziwy kryzys dopiero ma nadejść. Niemniej reakcją na tamte wydarzenia było zintensyfikowanie prac nad WESA. W efekcie jeszcze w 2011 i następnie w 2013 r. przyjęto kolejne dokumenty regulujące filary WESA i dostosowujące je do nowych ram traktatowych, a także sytuacji politycznej. 13 grudnia 2011 r. przyjęto Dyrektywę w sprawie norm dotyczących kwalifikowania obywateli państw trzecich lub bezpaństwowców jako beneficjentów ochrony międzynarodowej, jednolitego statusu uchodźców lub osób kwalifikujących się do otrzymania ochrony uzupełniającej oraz zakresu udzielanej ochrony, potocznie zwaną dyrektywą kwalifikacyjną ${ }^{13}$. Zastępowała ona dyrektywę

1 A. Nitszke, Europejski Urząd Wsparcia w dziedzinie Azylu (EASO). Zalożenia i praktyka funkcjonowania agencji $w$ dobie kryzysu migracyjnego, [w:] Unia Europejska i wybrane państwa świata wobec kryzysu migracyjnego, red. J. Nadolska, P. Stawar z, K. A. Wojt aszczyk, Warszawa 2017, s. 35-53.

12 P. Brill, Uchodźcy to problem nie tylko Włoch, „De Volkskrant”, 19.04.2011; cyt. za: EuroTopics, [on-line:] http://www.eurotopics.net/pl/home/debatten/links-2011-04-fluchtling/ - 5.05.2013.

13 Dyrektywa Parlamentu Europejskiego i Rady 2011/95/UE z dnia 13 grudnia 2011 r. w sprawie norm dotyczących kwalifikowania obywateli państw trzecich lub bezpaństwowców jako beneficjentów ochrony międzynarodowej, jednolitego statusu uchodźców lub osób kwalifikujących się do otrzymania ochrony uzupełniającej oraz zakresu udzielanej ochrony, Dz. Urz. UE L 337 z dnia 20 grudnia 2011 . Wielka Brytania i Irlandia skorzystały z klauzuli opt-out na podstawie protokołu 21 załączonego do traktatu lizbońskiego i nie związały się postanowieniami tego 
z 2004 r., której rozwiązania w wielu punktach były nieprecyzyjne i rodziły konflikty pomiędzy państwami członkowskimi. Najważniejszą zmianą w nowej dyrektywie było wprowadzenie katalogu wspólnych kryteriów identyfikacji osób ubiegających się o azyl i zagwarantowanie im minimalnego poziomu świadczeń we wszystkich państwach członkowskich UE. Dzięki temu rozwiązaniu można by uniknąć jednego $z$ najpoważniejszych problemów w zakresie polityki azylowej, a mianowicie przepływów wtórnych, przez które rozumie się wewnętrzną migrację osób ubiegających się o azyl w poszukiwaniu jak najkorzystniejszych warunków przyjęcia.

26 czerwca 2013 r. przyjęto następne cztery dokumenty regulujące kolejne filary WESA. Przede wszystkim należy zwrócić uwagę na rozporządzenie w sprawie ustanowienia kryteriów i mechanizmów ustalania państwa członkowskiego odpowiedzialnego za rozpatrzenie wniosku o udzielenie ochrony międzynarodowej złożonego $\mathrm{w}$ jednym $\mathrm{z}$ państw członkowskich przez obywatela państwa trzeciego lub bezpaństwowca, potocznie zwane rozporządzeniem Dublin III ${ }^{14}$, zastępujące rozporządzenie z 2003 r. (Dublin II). Rozporządzenie stworzyło nowe narzędzia do wczesnego wykrywania problemów w krajowych systemach azylowych i systemach przyjmowania osób ubiegających się o azyl. Miało także przyczynić się do sprawniejszego usuwania przyczyn owych problemów i w ten sposób nie dopuszczać do zaistnienia sytuacji kryzysowych. Dookreślono zasady i kryteria ustalania odpowiedzialności państw członkowskich za rozpatrzenie wniosku o azyl. Są to: po pierwsze, względy rodzinne; po drugie, niedawne posiadanie wizy lub zezwolenia na pobyt w kraju UE; po trzecie, fakt, czy wnioskodawca przekroczył granice UE legalnie, czy nie. Kolejny dokument dotyczył rozszerzenia systemu Eurodac ${ }^{15}$.

dokumentu. Oba państwa mają obowiązek stosowania w tym zakresie przepisów wynikających z Dyrektywy Rady 2004/83/WE z dnia 29 kwietnia 2004 r. w sprawie minimalnych standardów dla kwalifikacji i statusu obywateli państw trzecich lub bezpaństwowców jako uchodźców lub jako osób, które $z$ innych względów potrzebują ochrony międzynarodowej, oraz zakresu przyznawanej ochrony, Dz. Urz. UE L 304 z dnia 30 września 2004. Dania z kolei nie jest związana ani dyrektywą z 2004 r., ani dyrektywą z 2011 r., bowiem na podstawie protokołu 22 dołączonego do traktatu lizbońskiego nie uczestniczy w tym aspekcie integracji.

14 Rozporządzenie Parlamentu Europejskiego i Rady (UE) nr 604/2013 z dnia 26 czerwca 2013 r. w sprawie ustanowienia kryteriów i mechanizmów ustalania państwa członkowskiego odpowiedzialnego za rozpatrzenie wniosku o udzielenie ochrony międzynarodowej złożonego w jednym z państw członkowskich przez obywatela państwa trzeciego lub bezpaństwowca, $\mathrm{Dz}$. Urz. UE L 180 z dnia 29 czerwca 2013 r.

15 Rozporządzenie Parlamentu Europejskiego i Rady (UE) nr 603/2013 z dnia 26 czerwca 2013 r. w sprawie ustanowienia systemu Eurodac do porównywania odcisków palców w celu skutecznego stosowania rozporządzenia (UE) nr 604/2013 w sprawie ustanowienia kryteriów i mechanizmów ustalania państwa członkowskiego odpowiedzialnego za rozpatrzenie wniosku o udzielenie ochrony międzynarodowej złożonego $w$ jednym $z$ państw członkowskich przez 
Rozporządzenie wspiera stosowanie rozporządzenia Dublin III, umożliwiając odpowiednim służbom państw członkowskich UE oraz Europejskiego Obszaru Gospodarczego (EOG) dostęp do zgromadzonych zasobów. Ponadto daje ono nowe uprawnienia organom ścigania państw członkowskich oraz Europolowi: mogą one odtąd występować o udostępnienie baz w przypadkach, gdy uzyskane dane mogą być pomocne w prowadzonych śledztwach dotyczących poważnych przestępstw, w tym związanych z aktami terrorystycznymi. Oprócz dwóch wyżej przedstawionych rozporządzeń przyjęto dodatkowo dwie inne dyrektywy. Pierwsza z nich, tzw. dyrektywa proceduralna, określała wspólne procedury udzielania i cofania ochrony międzynarodowej ${ }^{16}$, zastępując dyrektywę z 2005 r. W dokumencie określono wspólne dla wszystkich państw członkowskich procedury, które mają być stosowane przy nadawaniu i cofaniu ochrony międzynarodowej. Wnioskodawcom zagwarantowano indywidualne, obiektywne i bezstronne rozpatrzenie wniosku. Mają oni również prawo do skutecznego odwołania przed sądem lub trybunałem, co wiąże się z zapewnieniem bezpłatnej pomocy prawnej. Określono także, że początkowy etap składania wniosków musi zakończyć się w ciągu sześciu miesięcy od ich złożenia. Dyrektywa czyni procedury ubiegania się o ochronę międzynarodową bardziej przejrzystymi i sprawiedliwymi w całej UE, a dziki temu również bardziej zrozumiałymi dla wnioskodawców. Kolejna dyrektywa, tzw. recepcyjna, dotyczy ustanowienia norm dotyczących przyjmowania wnioskodawców ubiegających się o ochronę międzynarodową ${ }^{17}$. Jest ona kluczowa, ponieważ ze względu na często zróżnicowany poziom warunków życia oferowany przez poszczególne państwa dochodziło do wtórnych przepływów osób ubiegających się o ochronę międzynarodową. Dyrektywa określa obowiązki państw członkowskich w zakresie gwarancji dla osób ubiegających się o ochronę międzynarodową. Są to m.in.: dostęp do zakwaterowania, opieka medyczna i psychologiczna, dostęp do edukacji dla dzieci poniżej 18. roku życia oraz

obywatela państwa trzeciego lub bezpaństwowca oraz w sprawie występowania o porównanie z danymi Eurodac przez organy ścigania państw członkowskich i Europol na potrzeby ochrony porządku publicznego, oraz zmieniające rozporządzenie (UE) nr 1077/2011 ustanawiające Europejską Agencję ds. Zarządzania Operacyjnego Wielkoskalowymi Systemami Informatycznymi w Przestrzeni Wolności, Bezpieczeństwa i Sprawiedliwości, Dz. Urz. UE L 180 z dnia 29 czerwca 2013 r.

16 Dyrektywa Parlamentu Europejskiego i Rady 2013/32/UE z dnia 26 czerwca 2013 r. w sprawie wspólnych procedur udzielania i cofania ochrony międzynarodowej, Dz. Urz. UE L 180 z dnia 29 czerwca 2013 r. Podobnie jak w przypadku dyrektywy kwalifikacyjnej Irlandia, Wielka Brytania i Dania nie są nią związane.

1) Dyrektywa Parlamentu Europejskiego i Rady 2013/33/UE z dnia 26 czerwca 2013 r. w sprawie ustanowienia norm dotyczących przyjmowania wnioskodawców ubiegających się o ochronę międzynarodową, Dz. Urz. UE L 180 z dnia 29 czerwca 2013 r. 
świadczenia pieniężne czy też dostęp do rynku pracy w ciągu dziewięciu miesięcy od zarejestrowania danej osoby.

\section{PROPOZYCJE REFORMY WESA PO KULMINACJI KRYZYSU}

\section{MICRACYJNEGO}

Powyższe rozwiązania miały pomóc UE i jej państwom członkowskim w sprawniejszym zarządzaniu polityką azylową. Jednak sytuacja międzynarodowa, w szczególności przedłużająca się wojna domowa w Syrii oraz działania tzw. Państwa Islamskiego spowodowały, że $\mathrm{w}$ kolejnych latach presja migracyjna nie osłabła, a w 2015 r. przybrała niespotykaną wcześniej skalę. Sytuacja była najpoważniejsza w tzw. państwach frontowych, czyli w Grecji i we Włoszech - to tam docierała bowiem największa liczba osób z państw trzecich ubiegających się o ochronę międzynarodową. W kwietniu 2015 r. Rada Europejska (RE) wezwała KE do opracowania nowego programu w dziedzinie polityki migracyjnej. 13 maja tego samego roku Komisja przedstawiła komunikat zatytułowany „Europejski program w zakresie migracji"18, który był podzielony na dwie części. W pierwszej przedstawiono środki, które powinny zostać podjęte natychmiast, tak by móc ograniczyć negatywne skutki presji migracyjnej, wspomóc państwa najbardziej narażone na presję migracyjną oraz zorganizować doraźną pomoc w ratowaniu migrantów próbujących dostać się do Europy drogą morską. Druga część programu dotyczyła działań do podjęcia w dłuższej perspektywie czasowej, a które miały stworzyć nowe ramy polityki migracyjnej i azylowej. Jednym z punktów zawartych w tej części było postanowienie mówiące o wzmocnieniu WESA ${ }^{19}$. Jesienią 2015 r. skala problemu była tak duża, że Niemcy zdecydowały się jednostronnie zawiesić niektóre postanowienia rozporządzenia Dublin III, czym naraziły się na krytykę ze strony innych państw członkowskich ${ }^{20}$. Pokazało to, że dotychczasowe rozwiązania WESA są niewystarczające i nie gwarantują sprawnego i sprawiedliwego zarządzania przepływami migracyjnymi, ze szczególnym odniesieniem do ich specyficznego rodzaju, czyli osób ubiegających się o ochronę międzynarodową. Na przełomie 2015 i 2016 r. okazało się, że UE samodzielnie nie jest w stanie

18 Komunikat Komisji do Parlamentu Europejskiego, Rady, Europejskiego Komitetu Ekonomiczno-Społecznego i Komitetu Regionów, Europejski program w zakresie migracji, Bruksela, 13.5.2015, COM(2015) 240 final.

19 Ibidem, s. 15-16, 21.

20 J. J. Węc, Reforma polityki imigracyjnej, kontroli granic zewnętrznych oraz polityki azylowej Unii Europejskiej w dobie kryzysu migracyjnego (2015-2016), „Przegląd Zachodni” 2017, nr 2, s. 9. 
podołać wyzwaniom migracyjnym. 23 września 2015 r. podczas nieformalnego szczytu RE określono nowe formy walki z kryzysem. Kluczowym partnerem okazała się Turcja. Jeszcze w listopadzie 2015 r. podczas szczytu UE - Turcja przyjęto plan działania ${ }^{21}$, który $w$ marcu kolejnego roku rozszerzono i sformalizowano poprzez zawarcie umowy ${ }^{22}$. Dzięki wdrożeniu w życie porozumienia z Turcją już w kolejnych tygodniach presja migracyjna na szlaku wschodniośródziemnomorskim znacznie osłabła ${ }^{23}$. Mimo pozytywnej oceny umowy z Turcją należy podkreślić, że było to działanie o charakterze doraźnym, dodatkowo bardzo kosztowne dla UE, tak w wymiarze finansowym (6 mld euro), jak i politycznym - zwłaszcza po nieudanym zamachu stanu w Turcji w lipcu $2016 \mathrm{r}$. i represjach politycznych wprowadzonych przez administrację prezydenta Recepa Erdoğana ${ }^{24}$. W tym czasie KE pracowała nad reformą WESA, czego efektem było przedstawienie w kwietniu 2016 r. komunikatu zatytułowanego „W kierunku reformy Wspólnego Europejskiego Systemu Azylowego i zwiększenia liczby legalnych sposobów migracji do Europy”25. Komisja zaznaczyła w nim, że „Kryzys ujawnił niedociągnięcia konstrukcji i stosowania wspólnego europejskiego systemu azylowego, w szczególności "systemu dublińskiego" "26. Zasadniczym kryterium ustalania państwa odpowiedzialnego za rozpatrzenie wniosku azylowego jest państwo pierwszego kontaktu. Takie rozwiązanie dyskryminuje państwa frontowe, powodując ich niewspółmierne obciążenie realizacją polityki azylowej całej Unii. Dodatkowo, w okresie zwiększonej presji migracyjnej, systemy tych państw nie były w stanie organizacyjnie podołać przyjmowaniu i rozpatrywaniu wniosków. To $\mathrm{z}$ kolei powodowało, że także po stronie osób ubiegających się o azyl widoczne było lekceważenie przepisów i udawanie się do wybranych przez siebie państw, w celu osiedlenia.

21 Szczyt przywódców UE z Turcją, 29.11.2015. Oświadczenie UE - Turcja, [on-line:] https:// www.consilium.europa.eu/pl/press/press-releases/2015/11/29/eu-turkey-meeting-statement/ - 25.03.2019.

22 Oświadczenie UE - Turcja. 18.03.2016, [on-line:] https://www.consilium.europa.eu/pl/press/ press-releases/2016/03/18/eu-turkey-statement/ - 25.03.2019.

23 Migration Flows: Eastern, Central, and Western Mediterranean Routes - Infografik, Monthly Irregular Arrivals, January 2015 to March 2019, [on-line:] https://www.consilium.europa.eu/ pl/infographics/eastern-and-central-mediterranean-routes-09-2017/ - 25.03.2019.

24 Stosunki UE-Turcja. Możliwe scenariusze rozwoju, [on-line:] http://www.europarl.europa.eu/ news/pl/headlines/world/20170426STO72401/stosunki-ue-turcja-mozliwe-scenariusze-roz woju -25.03 .2019 .

25 Komunikat Komisji do Parlamentu Europejskiego i Rady, W kierunku reformy Wspólnego Europejskiego Systemu Azylowego i zwiększenia liczby legalnych sposobów migracji do Europy, Bruksela, 6.04.2016, COM(2016) 197 final.

Ibidem, s. 3. 
Wtórne przepływy skutkowały $\mathrm{z}$ kolei przywracaniem przez niektóre państwa kontroli na wewnętrznych granicach państw członkowskich. Także inne rozwiązania WESA obarczone były niedoskonałościami. Trzy dyrektywy - kwalifikacyjna, recepcyjna i proceduralna - zostały implementowane przez państwa członkowskie, jednak skutki prawne dla osób ubiegających się o ochronę międzynarodową w poszczególnych państwach różnią się. To także generuje, wcześniej wspomniane, zjawisko wtórnych przepływów.

Komisja, mając na względzie doświadczenia poprzednich trzech lat, zwłaszcza roku 2015, zaproponowała w komunikacie rozpoczęcie ogólnoeuropejskiej debaty na temat nowych ram WESA tak, by z jednej strony, zabezpieczyć interesy UE i jej państw członkowskich, a z drugiej - nadal realizować wysokie standardy międzynarodowe w zakresie ochrony osób potrzebujących ochrony międzynarodowej. 4 maja i 14 lipca 2016 r. KE przedłożyła, zgodnie z zapowiedzią, pakiet siedmiu wniosków ustawodawczych, których celem ogólnym miała być reforma WESA, zaś celami szczegółowymi - usunięcie wad i słabości w dotychczasowych filarach systemu oraz propozycja nowego rozwiązania dotyczącego systemu przesiedleń.

Wniosek w sprawie przekształcenia rozporządzenia Dublin III miał na celu doprecyzowanie kwestii odpowiedzialności państw za rozpatrzenie wniosku o udzielenie azylu. Propozycja Komisji zakładała także wprowadzenie mechanizmu korekcyjnego przydziału wniosków, co gwarantowało sprawiedliwy podział odpowiedzialności między państwa członkowskie, uwzględniając także wnioski osób wysadzonych na ląd w następstwie operacji poszukiwawczo-ratowniczych. Nowe rozwiązania miałyby też ograniczyć, a finalnie całkowicie wyeliminować, przepływy wtórne ${ }^{27}$. Dotychczas prawodawcom unijnym nie udało się osiągnąć kompromisu w tej sprawie ${ }^{28}$. Kolejny wniosek dotyczył zmian w rozporządzeniu Eurodac. Reforma miałaby ulepszyć system poprzez poszerzenie ilości zbieranych danych, np. wizerunku twarzy, czy też możliwość gromadzenia danych osób, których status $w$ UE jest nieuregulowany, a które nie ubiegają się o azyl ${ }^{29}$. Z uwa-

27 Wniosek: Rozporządzenie Parlamentu Europejskiego i Rady w sprawie ustanowienia kryteriów i mechanizmów ustalania państwa członkowskiego odpowiedzialnego za rozpatrzenie wniosku o udzielenie ochrony międzynarodowej złożonego $w$ jednym $z$ państw członkowskich przez obywatela państwa trzeciego lub bezpaństwowca (wersja przekształcona), Bruksela, 4.5.2016, COM(2016) 270 final 2016/0133 (COD), s. 4.

28 Rada Unii Europejskiej. Nota, Bruksela, 26.02.2019 (OR. en) 6600/19, s. 3, [on-line:] http:// data.consilium.europa.eu/doc/document/ST-6600-2019-INIT/PL/pdf - 25.03.2019.

29 Proposal for a Regulation of the European Parliament and of the Council on the European Union Agency for Asylum and repealing Regulation (EU) No 439/2010, Brussels, 4.05.2016, COM(2016) 271 final 2016/0131 (COD). 
gi na problemy związane m.in. z uzgodnieniem stanowiska w sprawie reformy rozporządzenia Dublin III prawodawcom unijnym nie udało się przyjąć zreformowanego rozporządzenia, choć - jak zaznacza Rada na swojej stronie internetowej - udało się wypracować szerokie porozumienie polityczne z $\mathrm{PE}^{30}$. Trzeci wniosek przedłożony przez Komisję dotyczył przekształcenia EASO w Agencję Unii Europejskiej ds. Azylu ${ }^{31}$. Zgodnie z wnioskiem mandat Agencji, oprócz dotychczas realizowanych zadań, miałby zostać poszerzony o ocenę zbieżności wniosków o ochronę międzynarodową, o udzielanie państwom członkowskim pomocy operacyjnej i technicznej oraz identyfikację i rejestrację osób ubiegających się o azyl, choć z zastrzeżeniem, że ostateczne decyzje będą w tym zakresie należeć do państw członkowskich. Podobnie jak w przypadku wniosku w sprawie rozporządzenia Eurodac, tak i tym razem, mimo zakończenia prac legislacyjnych w 2017 r., przyjęcie rozporządzenia jest warunkowane przyjęciem propozycji reform pozostałych elementów WESA ${ }^{32}$. Trzy kolejne wnioski Komisji dotyczyły rozporządzenia ustanawiającego wspólną procedurę ubiegania się o ochronę międzynarodową w UE, rozporządzenia o kwalifikowaniu oraz przekształcenia dyrektywy o warunkach przyjmowania. Komisja proponuje zastąpienie dotychczasowej dyrektywy proceduralnej rozporządzeniem i ustanowieniem wspólnej procedury ochrony międzynarodowej ${ }^{33}$. Ujednolicenie przepisów wyeliminowałoby istniejące aktualnie różnice w krajowych procedurach. Dzięki temu zniknęłaby pokusa tzw. turystyki azylowej i ograniczone zostałyby przepływy wtórne. Wniosek Komisji nadal jest procedowany. Nie udało się dotychczas osiągnąć kompromisu, m.in. z powodu definiowania pewnych kwestii, w tym określenia procedury granicznej i jej dokładnego zakresu oraz terminu „ostateczna decyzja”, użytego w art. 4 wniosku Komisji ${ }^{34}$. W zakresie procedury kwalifikacyjnej Komisja także proponuje zastąpienie dyrektywy rozporządzeniem ${ }^{35}$. Celem

30 Reforma unijnych przepisów azylowych, [on-line:] https://www.consilium.europa.eu/pl/ policies/ceas-reform/ - 25.03.2019.

${ }^{31}$ Wniosek: Rozporządzenie Parlamentu Europejskiego i Rady w sprawie Agencji Unii Europejskiej ds. Azylu i uchylające rozporządzenie (UE) nr 439/2010, Bruksela, 4.05.2016, COM(2016) 271 final 2016/0131(COD).

32 Reforma unijnych przepisów azylowych, op. cit.

33 Wniosek: Rozporządzenie Parlamentu Europejskiego i Rady ustanawiające wspólną procedurę ubiegania się o ochronę międzynarodową w Unii i uchylające dyrektywę 2013/32/UE, COM/2016/0467 final 2016/0224 (COD).

34 Rada Unii Europejskiej. Nota, s. 6.

35 Wniosek: Rozporządzenie Parlamentu Europejskiego i Rady w sprawie norm dotyczących kwalifikowania obywateli państw trzecich lub bezpaństwowców jako osób korzystających z ochrony międzynarodowej, jednolitego statusu uchodźców lub osób kwalifikujących się do otrzymania ochrony uzupełniającej oraz zakresu udzielanej ochrony oraz zmieniające dyrekty- 
Komisji jest zrównanie traktowania osób ubiegających się o azyl we wszystkich państwach członkowskich. Proponuje zatem wspólne kryteria identyfikowania osób rzeczywiście potrzebujących ochrony międzynarodowej, a także jednakowe prawa dla nich we wszystkich państwach członkowskich. W przypadku tego wniosku pojawiły się rozbieżności między stanowiskiem Rady i Parlamentu. Do stycznia 2019 r. nie udało się osiągnąć porozumienia ${ }^{36}$. Zmiany w dyrektywie recepcyjnej mają polegać na określeniu "standardowych warunków przyjęcia”, co skutkowałoby wyrównaniem poziomu warunków bytowych oferowanych przez państwa osobom ubiegającym się o ochronę międzynarodową ${ }^{37}$. Najważniejszą zmianą proponowaną przez Komisję jest ustanowienie ograniczeń geograficznych w przemieszczaniu ubiegających się o azyl osób. Wnioskodawca mógłby korzystać z warunków przyjęcia tylko w państwie, w którym złożył wniosek azylowy. Dodatkowo państwa mogłyby wprowadzić ograniczenia przemieszczania się na swoim terytorium do określonego obszaru. Także to rozwiązanie miałoby ograniczyć przepływy wtórne. Ten wniosek Komisji dotychczas nie został przyjęty $z$ uwagi na rozbieżność stanowisk PE i Rady ${ }^{38}$. Komisja przedstawiła również wniosek dotyczący rozporządzenia ustanawiającego unijne ramy przesiedleń $^{39}$ - jest to jeden $\mathrm{z}$ najtrudniejszych tematów, $\mathrm{z}$ którymi przyszło zmierzyć się UE w ostatnich latach. Propozycje Komisji dotyczące mechanizmów relokacji i przesiedleń, przedstawione w 2015 r., uwidoczniły znaczące różnice w stanowiskach państw. Aby na przyszłość uniknąć konieczności stosowania rozwiązań doraźnych, których skuteczność jest niewielka, Komisja opracowała mechanizm stałych unijnych przesiedleń. Miałby on, z jednej strony, zapewnić realizację priorytetów Unii na arenie międzynarodowej jako organizacji, która bierze odpowiedzialność w sytuacjach kryzysów humanitarnych, a z drugiej - dbać o interesy państw członkowskich, szczególnie tych, które $\mathrm{z}$ uwagi na położenie geograficzne są narażone na zwiększoną presję migracyjną. Mechanizm określałby udział poszczególnych państw w przyjmowaniu uchodźców. Rada, na wniosek Komisji, przyjmowałaby dwuletni plan przesiedleń i przyjęć ze względów humanitarnych.

wę Rady 2003/109/WE z dnia 25 listopada 2003 r. dotyczącą statusu obywateli paŕstw trzecich będących rezydentami długoterminowymi, COM/2016/0466 final 2016/0223 (COD).

36 Rada Unii Europejskiej. Nota, s. 5.

37 Wniosek: Dyrektywa Parlamentu Europejskiego i Rady w sprawie ustanowienia norm dotyczących przyjmowania osób ubiegających się o ochronę międzynarodową (wersja przekształcona), COM/2016/0465 final 2016/0222 (COD).

38 Rada Unii Europejskiej. Nota, s. 4.

39 Wniosek: Rozporządzenie Parlamentu Europejskiego i Rady ustanawiające unijne ramy przesiedleń i zmieniające rozporządzenie Parlamentu Europejskiego i Rady (UE) nr 516/2014, COM/2016/0468 final 2016/0225 (COD). 
Wniosek Komisji dotychczas nie został przyjęty. Ponownie ujawniły się różnice zdań między Parlamentem i Radą ${ }^{40}$.

\section{PoDsIMOMANIE I KONKLLZJE.}

Kryzys migracyjny po ośmiu latach od jego początku nadal budzi duże emocje w państwach członkowskich i jest ciągle aktualnym tematem na forach instytucji unijnych. W pierwszej fazie kryzysu udało się dokończyć tworzenie WESA. Trudno jednoznacznie przesądzić, czy działania podejmowane w latach 20102013 były konsekwencją pierwszych symptomów kryzysu, czy wynikały raczej $\mathrm{z}$ nowych ram traktatowych i konieczności dostosowania prawa wtórnego w zakresie polityki azylowej do postanowień traktatu lizbońskiego. Zapewne oba te elementy lącznie miały wpływ na prace nad WESA - traktat lizboński wpłynął na kształt ram prawnych, natomiast sam kryzys miał wpływ na ich treść. Szybko okazało się jednak, że wprowadzone rozwiązania nie są skutecznym narzędziem w zarządzaniu polityką azylową w sytuacji kryzysu. W zasadzie każdy z elementów WESA okazał się w mniejszym lub większym stopniu niefunkcjonalny w obliczu zwiększonej presji migracyjnej. Dlaczego tak się stało? Jednym z najważniejszych powodów takiego stanu rzeczy było nastawienie państw członkowskich. O ile nikt nie kwestionował zasadności realizacji przez UE polityki azylowej i obowiązku wynikającego nie tylko z prawa unijnego, ale także z przepisów prawa międzynarodowego publicznego, niesienia pomocy osobom, których zdrowie lub życie są zagrożone w efekcie toczących się konfliktów lub prześladowań na tle religijnym, rasowym bądź politycznym, o tyle sporna pozostawała kwestia środków, jakie powinny być zastosowane. Najpoważniejsze kontrowersje pojawiły się w $2015 \mathrm{r}$. i były związane z propozycją KE dotyczącą systemu relokacji oraz przesiedleń. Mechanizm zaproponowany przez Komisję, a następnie przyjęty przez Radę, oznaczał rozłożenie odpowiedzialności za zarządzanie kryzysem pomiędzy wszystkie państwa członkowskie, bez względu na ich położenie geograficzne ${ }^{41}$.

40 Rada Unii Europejskiej. Nota, s. 8-9.

4127 maja 2015 r. KE przedstawila wniosek ustawodawczy ws. tymczasowego mechanizmu relokacji oraz zalecenie dotyczące dobrowolnego systemu przesiedleń. Relokacja miała objąć 40 tys. uchodźców z Włoch i Grecji; dotyczyła także przesiedlenia kolejnych 20 tys. uchodźców w latach 2015-2016. Komunikat Komisji do Parlamentu Europejskiego, Rady, Europejskiego Komitetu Ekonomiczno-Społecznego i Komitetu Regionów, s. 22-26. 9 września 2015 r. KE przedstawiła II pakiet środków - dalsza relokacja - 120 tys. uchodźców z Grecji, Włoch i Węgier. 22 września RUE podjęła decyzję o relokacji z Włoch i Grecji przy sprzeciwie Węgier, 
Było to zatem rozwiązanie $w$ założeniu zgodne $\mathrm{z}$ postanowieniami art. $80 \mathrm{TFUE}$, czyli z zasadą solidarności tam określoną. Z punktu widzenia państw frontowych mechanizm relokacji i przesiedleń był korzystny, jednak państwa Europy Środkowo-Wschodniej od początku były sceptyczne wobec tej idei.

Umowa z Turcją zawarta w 2016 r. pomogła opanować napiętą sytuację, co mogło stać się impulsem do wznowienia prac nad reformą WESA. KE, która opracowała program reformy systemu azylowego, okazała się jednak zbyt słaba politycznie, by przekonać prawodawców unijnych do kompleksowego uregulowania polityki azylowej poprzez oparcie ich na doświadczeniach zdobytych podczas kryzysu migracyjnego. Pisząc o przekonaniu prawodawców unijnych, należy poczynić ważną uwagę. Otóż stanowisko PE w większości kwestii było zbieżne z pomysłami przedstawionymi przez Komisję. A zatem problem leżał po stronie drugiego z prawodawców unijnych, czyli w Radzie. Wniosek z tego jest taki, że to różnice stanowisk poszczególnych państw członkowskich spowodowały, że od połowy $2016 \mathrm{r}$. nie udało się przyjąć pakietu siedmiu wniosków ustawodawczych reformujących $W_{E S A}{ }^{42}$. Przykładem rozbieżności stanowisk państw w odniesieniu do propozycji KE dotyczących reformy WESA był tzw. miniszczyt w sprawie migracji, który odbył się 24 czerwca 2018 r. W spotkaniu nie wzięli udziału przywódcy aż 12 państw członkowskich: Litwy, Łotwy, Estonii, Polski, Czech, Słowacji, Węgier, Portugalii, Rumunii, Cypru, Irlandii i Wielkiej Brytanii. Ich absencja była wyrazem sprzeciwu wobec propozycji reformy WESA ${ }^{43}$. W grudniu tego samego roku, podczas spotkania RE, zaakcentowano konieczność dalszych prac nad reformą WESA ${ }^{44}$. Jednak, jak już wcześniej zaznaczono, dotychczas nie udało się osiągnąć porozumienia w sprawie kompleksowego uregulowania nowej polityki azylowej UE.

Kryzys wykazał, że solidarność państw członkowskich w obliczu zwiększonej presji migracyjnej pozostaje jedynie deklaracją, a tym, co istnieje realnie, są par-

Czech, Słowacji i Rumunii. Do września 2017 r. relokacja objęła 28 tys. osób. Od 2015 r. do września 2017 r. przesiedlono 20 tys. uchodźców (w tym 9 tys. z obozów w Turcji).

42 Rada Unii Europejskiej. Nota, s. 2-9.

43 M. Strzałkowski, Miniszczyt UE ws. migracji bez konkretów, [on-line:] https://www.euractiv.pl/section/migracje/news/miniszczyt-ws-migracji-bez-konkretow-ale-podzial-w-uecoraz-bardziej-widoczny/ - 25.03.2019. Wcześniej, 21 czerwca 2018 r., odbyło się spotkanie przywódców państw Grupy Wyszehradzkiej z kanclerzem Austrii. Państwa wyszehradzkie zapowiedziały tam bojkot „miniszczytu”, przede wszystkim z powodu propozycji dotyczących systemu relokacji, na które to rozwiązanie państwa te nie godziły się od początku.

44 Posiedzenie Rady Europejskiej 13 i 14 grudnia 2018 r. Konkluzje, Bruksela, 14.12.2018, [on-line:] https://www.consilium.europa.eu/media/37556/13-14-euco-final-conclusions-pl.pdf - 25.03.2019. 
tykularne interesy państwowe. Podczas analizy konsekwencji kryzysu migracyjnego, ze szczególnym uwzględnieniem polityki azylowej, należy podkreślić ich wielowymiarowy charakter. Z perspektywy UE kryzys obnażył słabości WESA, ale także słabość instytucji UE, które nie potrafiły przedstawić pozytywnego średnio- oraz długoterminowego planu działania, który byłby do przyjęcia przez wszystkie państwa członkowskie. Z perspektywy państw członkowskich kryzys pokazał brak solidarności, ale też z drugiej strony - brak chęci szerszego dialogu z państwami, które są wstrzemięźliwe wobec wizji przyjmowania uchodźców. To $\mathrm{z}$ kolei jest podyktowane $\mathrm{w}$ dużej mierze bieżącą polityką krajową. Kryzys migracyjny jest wykorzystywany instrumentalnie przez partie polityczne w różnych państwach członkowskich, które odwołują się do strachu i utraty poczucia bezpieczeństwa, w tym socjalnego ${ }^{45}$.

We wstępie postawiono hipotezę mówiącą, że kryzys migracyjny, zwłaszcza jego kulminacja $z$ lat 2015-2016, wpłynął na wypracowanie i przyjęcie skuteczniejszych mechanizmów w polityce azylowej, które pozwolą efektywniej zarządzać kolejnymi zwiększonymi migracjami do UE. Analiza działań KE mogłaby potwierdzać tę tezę - kolejno przedstawiane plany działań w zakresie polityki migracyjnej i idące za nimi wnioski ustawodawcze, a zwłaszcza pakiet siedmiu wniosków z maja i lipca 2016 r. wskazują, że Komisja wyraźnie dostrzegała potrzebę reformy WESA i, wyciągając wnioski z doświadczeń kryzysu migracyjnego, proponowała systemowe rozwiązania, które mogłyby w przyszłości pomóc UE w zarządzaniu podobnymi kryzysami. Jednak analiza losów poszczególnych wniosków KE dotyczących reformy WESA wskazuje, że prawodawcy unijni - PE i Rada - nie są w stanie osiągnąć kompromisu. Stanowisko PE jest zwykle zbieżne z propozycjami KE, gdy tymczasem Rada, w której zasiadają reprezentanci rządów państw członkowskich, często kieruje się partykularnymi interesami, w tym doraźnym interesem politycznym partii, której konkretny minister jest przedstawicielem. Reasumując, UE wprawdzie w dramatycznych okolicznościach, ale miała niepowtarzalną okazję, aby przeprowadzić skuteczną i kompleksową reformę WESA, przygotowując się na kolejne kryzysy w sposób zinstytucjonalizowany. Okazja ta nie została jednak wykorzystana, a dyskusję na temat reformy WESA zdominowały kwestie pozamerytoryczne, często nacechowane populistycznie.

15 Niemal $w$ każdym państwie UE istnieją dziś partie populistyczne i nacjonalistyczne głoszące hasła antyimigranckie. I choć jeszcze dekadę temu nie mogły one liczyć na przekroczenie progu wyborczego, dzisiaj pretendują do sprawowania władzy, m.in. francuski Front Narodowy (Front National - FN), Prawdziwi Finowie (Perussuomalaiset - PS), Wolnościowa Partia Austrii (Freiheitliche Partei Österreichs - FPÖ). 


\section{BIBLIOGRAFIA}

\section{Dokumenty}

Dyrektywa Parlamentu Europejskiego i Rady 2011/95/UE z dnia 13 grudnia 2011 r. w sprawie norm dotyczących kwalifikowania obywateli państw trzecich lub bezpaństwowców jako beneficjentów ochrony międzynarodowej, jednolitego statusu uchodźców lub osób kwalifikujących się do otrzymania ochrony uzupełniającej oraz zakresu udzielanej ochrony, Dz. Urz. UE L 337 z dnia 20 grudnia 2011 r.

Dyrektywa Parlamentu Europejskiego i Rady 2013/32/UE z dnia 26 czerwca 2013 r. w sprawie wspólnych procedur udzielania i cofania ochrony międzynarodowej, Dz. Urz. UE L 180 z dnia 29 czerwca 2013 r.

Dyrektywa Parlamentu Europejskiego i Rady 2013/33/UE z dnia 26 czerwca 2013 r. w sprawie ustanowienia norm dotyczących przyjmowania wnioskodawców ubiegających się o ochronę międzynarodową, Dz. Urz. UE L 180 z dnia 29 czerwca 2013 r.

Dyrektywa Rady 2004/83/WE z dnia 29 kwietnia 2004 r. w sprawie minimalnych standardów dla kwalifikacji i statusu obywateli państw trzecich lub bezpaństwowców jako uchodźców lub jako osób, które $z$ innych względów potrzebują ochrony międzynarodowej, oraz zakresu przyznawanej ochrony, Dz. Urz. UE L 304 z dnia 30 września 2004 r.

Komunikat Komisji do Parlamentu Europejskiego, Rady, Europejskiego Komitetu Ekonomiczno-Społecznego i Komitetu Regionów, „Europejski program w zakresie migracji”, Bruksela, 13.5.2015, COM(2015) 240 final.

Komunikat Komisji do Parlamentu Europejskiego i Rady „W kierunku reformy Wspólnego Europejskiego Systemu Azylowego i zwiększenia liczby legalnych sposobów migracji do Europy", Bruksela, 6.4.2016, COM(2016) 197 final.

Oświadczenie UE - Turcja, 18.03.2016, [on-line:] https://www.consilium.europa.eu/pl/press/ press-releases/2016/03/18/eu-turkey-statement/ - 25.03.2019.

Rada Unii Europejskiej. Nota, Bruksela, 26.02.2019 (OR. en) 6600/19, [on-line:] http://data. consilium.europa.eu/doc/document/ST-6600-2019-INIT/PL/pdf - 29.03.2019.

Posiedzenie Rady Europejskiej 13 i 14 grudnia 2018 r. Konkluzje, Bruksela, 14.12.2018, [on-line:] https://www.consilium.europa.eu/media/37556/13-14-euco-final-conclusions -pl.pdf - 25.03.2019.

Proposal for a Regulation of the European Parliament and of the Council on the European Union Agency for Asylum and Repealing Regulation (EU) No 439/2010, Brussels, 4.05.2016, COM(2016) 271 final 2016/0131 (COD).

Rozporządzenie Parlamentu Europejskiego i Rady (UE) nr 439/2010 z dnia 19 maja 2010 r. w sprawie utworzenia Europejskiego Urzędu Wsparcia w dziedzinie Azylu, Dz. Urz. UE L 132 z dnia 29 maja 2010 r.

Rozporządzenie Parlamentu Europejskiego i Rady (UE) nr 603/2013 z dnia 26 czerwca 2013 r. w sprawie ustanowienia systemu Eurodac do porównywania odcisków palców w celu skutecznego stosowania rozporządzenia (UE) $\mathrm{nr}$ 604/2013 w sprawie ustanowienia kryteriów i mechanizmów ustalania państwa członkowskiego odpowiedzialnego za rozpatrzenie wniosku o udzielenie ochrony międzynarodowej złożonego $w$ jednym $z$ państw członkowskich przez obywatela państwa trzeciego lub bezpaństwowca oraz $w$ sprawie występowania o porównanie $z$ danymi Eurodac przez organy ścigania państw członkowskich i Europol na potrzeby ochrony porządku publicznego, oraz zmieniające rozporządzenie (UE) nr 1077/2011 ustanawiające Europejską Agen- 
cję ds. Zarządzania Operacyjnego Wielkoskalowymi Systemami Informatycznymi w Przestrzeni Wolności, Bezpieczeństwa i Sprawiedliwości, Dz. Urz. UE L 180 z dnia 29 czerwca $2013 \mathrm{r}$.

Rozporządzenie Parlamentu Europejskiego i Rady (UE) nr 604/2013 z dnia 26 czerwca 2013 r. w sprawie ustanowienia kryteriów i mechanizmów ustalania państwa członkowskiego odpowiedzialnego za rozpatrzenie wniosku o udzielenie ochrony międzynarodowej złożonego $w$ jednym $z$ państw członkowskich przez obywatela państwa trzeciego lub bezpaństwowca, Dz. Urz. UE 180 z dnia 29 czerwca 2013 r.

Tampere European Council 15 and 16 October 1999, Presidency Conclusions, s. 2-3, [on-line:] https://www.consilium.europa.eu/media/21059/tampere-european-councilpresidency-conclusions.pdf, 25.03.2019.

Traktat o funkcjonowaniu Unii Europejskiej, Dz. Urz. UE C 202 z dnia 7 czerwca 2018 r.

Wniosek: Dyrektywa Parlamentu Europejskiego i Rady w sprawie ustanowienia norm dotyczących przyjmowania osób ubiegających się o ochronę międzynarodową (wersja przekształcona), COM/2016/0465 final 2016/0222 (COD).

Wniosek: Rozporządzenie Parlamentu Europejskiego i Rady ustanawiające unijne ramy przesiedleń i zmieniające rozporządzenie Parlamentu Europejskiego i Rady (UE) nr 516/2014, COM/2016/0468 final 2016/0225 (COD).

Wniosek: Rozporządzenie Parlamentu Europejskiego i Rady ustanawiające wspólną procedurę ubiegania się o ochronę międzynarodową w Unii i uchylające dyrektywę 2013/32/ UE, COM/2016/0467 final 2016/0224 (COD).

Wniosek: Rozporządzenie Parlamentu Europejskiego i Rady w sprawie Agencji Unii Europejskiej ds. Azylu i uchylające rozporządzenie (UE) nr 439/2010, Bruksela, 4.05.2016, $\operatorname{COM}(2016) 271$ final 2016/0131(COD).

Wniosek: Rozporządzenie Parlamentu Europejskiego i Rady w sprawie norm dotyczących kwalifikowania obywateli państw trzecich lub bezpaństwowców jako osób korzystających z ochrony międzynarodowej, jednolitego statusu uchodźców lub osób kwalifikujących się do otrzymania ochrony uzupełniającej oraz zakresu udzielanej ochrony oraz zmieniające dyrektywę Rady 2003/109/WE z dnia 25 listopada 2003 r. dotyczącą statusu obywateli państw trzecich będących rezydentami długoterminowymi, COM/2016/0466 final 2016/0223 (COD).

Wniosek: Rozporządzenie Parlamentu Europejskiego i Rady w sprawie ustanowienia kryteriów i mechanizmów ustalania państwa członkowskiego odpowiedzialnego za rozpatrzenie wniosku o udzielenie ochrony międzynarodowej złożonego $w$ jednym z państw członkowskich przez obywatela państwa trzeciego lub bezpaństwowca (wersja przekształcona), Bruksela, 4.05.2016, COM(2016) 270 final 2016/0133 (COD).

\section{Inne}

Azyl i migracja. Wszyscy na tym samym wózku, 20.12.2016, [on-line:] https://www.unhcr.org/ pl/235-plco-robimymonitorowanie-granicazyl-i-migracja-html.html - 25.03.2019.

Kryzys [hasło], [w:] Słownik języka polskiego PWN, [on-line:] https://sjp.pwn.pl/sjp/kryzys; 2565070.html - 25.04.2019.

Migration Flows: Eastern, Central, and Western Mediterranean routes - Infografik, Monthly Irregular Arrivals, January 2015 to March 2019, [on-line:] https://www.consilium.europa. $\mathrm{eu} / \mathrm{pl} / \mathrm{infographics} /$ eastern-and-central-mediterranean-routes-09-2017/ - 25.03.2019.

Nitszke A., Europejski Urząd Wsparcia w dziedzinie Azylu (EASO). Założenia i praktyka funkcjonowania agencji $w$ dobie kryzysu migracyjnego, [w:] Unia Europejska i wybrane pań- 
stwa świata wobec kryzysu migracyjnego, red. J. Nadolska, P. Stawarz, K. A. Wojtaszczyk, Warszawa 2017, s. 35-53.

Nitszke A., Polityka azylowa Unii Europejskiej. Między idealizmem a realizmem, [w:] Dylematy strategiczne XXI wieku, red. R. Kłosowicz, B. Szlachta, J. J. Węc, Kraków 2013, s. 353-365.

Przyszłość polityki migracyjnej, Komisja Europejska. Przedstawicielstwo w Polsce, 7.12.2017, [on-line:] https://ec.europa.eu/poland/news/171207_migration_pl - 25.03.2019.

Reforma unijnych przepisów azylowych, [on-line:] https://www.consilium.europa.eu/pl/poli cies/ceas-reform/ - 25.03.2019.

Stosunki UE-Turcja: Możliwe scenariusze rozwoju, [on-line:] http://www.europarl.europa.eu/ news/pl/headlines/world/20170426STO72401/stosunki-ue-turcja-mozliwe-scenariu sze-rozwoju - 25.03.2019.

Strzałkowski M., Miniszczyt UE ws. migracji bez konkretów, [on-line:] https://www.euractiv. $\mathrm{pl} /$ section/migracje/news/miniszczyt-ws-migracji-bez-konkretow-ale-podzial-w-uecoraz-bardziej-widoczny/ - 25.03.2019.

Szczyt przywódców UE z Turcją, 29.11.2015. Oświadczenie UE - Turcja, [on-line:] https:// www.consilium.europa.eu/pl/press/press-releases/2015/11/29/eu-turkey-meeting -statement/ - 25.03.2019.

Weinzierl R., Flüchtlinge. Schutz und Abwehr in der erweiterten EU. Funktionsweise, Folgen und Perspektiven der europäischen Integration, Baden-Baden 2005, Schriftenreihe europäisches Recht, Politik und Wirtschaft, Bd. 308.

Węc J. J., Reforma polityki imigracyjnej, kontroli granic zewnętrznych oraz polityki azylowej Unii Europejskiej w dobie kryzysu migracyjnego (2015-2016), "Przegląd Zachodni” 2017, nr 2, s. 7-39.

Wróbel I., Wspólny europejski system azylowy - stan obecny i perspektywy rozwoju, Warszawa 2012, s. 6-7, Materiały Robocze, 1 (17).

AGNIESZKA ANNA NITSZKE - doktor nauk humanistycznych w zakresie nauk politycznych. Adiunkt w Katedrze Studiów nad Procesami Integracyjnymi w Instytucie Nauk Politycznych i Stosunków Międzynarodowych UJ. Autorka m.in. monografii Zasady ustroju federalnego w panstwach niemieckojęzycznych. Studium porównawcze (2013), System agencji Unii Europejskiej (2017) oraz artykułów poświęconych integracji europejskiej i partiom politycznym w Europie. 